\title{
ITS2 as a molecular marker for the identification of Diatraea saccharalis and D. flavipennella and possible infection with Cotesia spp
}

\author{
M.S. Regueira Neto ${ }^{1}$, R.P. Barros ${ }^{2}$, M.A.J. Morais ${ }^{3}$, V.Q. Balbino ${ }^{1}$ and \\ V. Loreto ${ }^{2}$ \\ ${ }^{1}$ Laboratório de Bioinformática e Biologia Evolutiva, \\ Departamento de Genética, Centro de Ciências Biológicas, \\ Universidade Federal de Pernambuco, Recife, PE, Brasil \\ ${ }^{2}$ Laboratório de Genética e Citogenética Animal, \\ Departamento de Genética, Centro de Ciências Biológicas, \\ Universidade Federal de Pernambuco, Recife, PE, Brasil \\ ${ }^{3}$ Laboratório de Genética de Microrganismo, Departamento de Genética, \\ Universidade Federal de Pernambuco, Recife, PE, Brasil \\ Corresponding author: M.S. Regueira Neto \\ E-mail: marcosregueira10@hotmail.com
}

Genet. Mol. Res. 16 (3): gmr16039732

Received May 22, 2017

Accepted July 21, 2017

Published August 31, 2017

DOI http://dx.doi.org/10.4238/gmr16039732

Copyright (C 2017 The Authors. This is an open-access article distributed under the terms of the Creative Commons Attribution ShareAlike (CC BY-SA) 4.0 License.

\begin{abstract}
In Brazil, the species Diatraea flavipennella and D. saccharalis play an important role in the sugar and alcohol agribusiness by causing many damages in sugarcane fields. The egg, larva, pupa, and adult stages are very morphologically similar between these species, and the identification can be confused. The internal transcribed spacer 2 (ITS 2) from ribosomal DNA has important features as evolutionary divergence. It is a good marker for species identification, participates in the rDNA processing, and has been applied in phylogenetic and population studies. This study aimed to make available a molecular marker to assist on the identification method of pests' species of Diatraea and to identify possible traces of Cotesia in the resistant host.
\end{abstract}

Genetics and Molecular Research 16 (3): gmr16039732 
The DNA was extracted from the egg, larva, and adult samples. PCR amplicons were purified and sequenced. The sequences were analyzed in MEGA 5.01. The ITS 2 length was $410 \mathrm{bp}$ in D. flavipennella and 448 bp in $D$. saccharalis. The GC content was similar between the species. Three microsatellite loci were present in D. saccharalis and absent in D. flavipennella, contributing to differences in ITS 2 length in the species. An additional 367-bp band was attributed to Cotesia spp. The differences among ITS 2 from $D$. flavipennella, D. saccharalis, and Cotesia sp were sufficient to identify them on electrophoresis gel and sequencing. The presence of Cotesia sp traits in adult D. flavipennella showed possible host refractoriness, but further studies are necessary.

Key words: Diatraea; Internal transcribed spacer 2; Lepidoptera; Molecular identification

\section{INTRODUCTION}

In sugarcane fields (Saccharum complex) from Brazil, two Lepidoptera species highlight in a range of insect species that attack the sugarcane and bring many damages to the sugar-ethanol agribusiness. Diatraea saccharalis (Fabricius, 1794) and D. flavipennella (Box, 1931), most known as the little sugarcane moth borer, are widespread in the Brazilian territory, and can occur in other cultures as maize, sorghum, and rice (Hall et al., 1991; Bortoli et al., 2005; Araújo et al., 2010).

Diatraea saccharalis occurs throughout the Brazilian territory, while D. flavipennella is present in the states of Northeast and some states of the southeast. Freitas et al. (2006) described an overcoming in the potential plague of $D$. flavipennella over $D$. saccharalis in the State of Alagoas, where this overcoming is probably caused by the methods adopted for biological control.

Both species can occur at the same time in the sugarcane field, and all developmental stages can be found simultaneously through the year. In the egg stage, the morphology of both species is identical with white color in the early age, becoming orange and dark before hatching. The larval stage is very similar in both species with slight differences between them, D. flavipennella presents a brownish yellow head capsule while D. saccharalis presents a brownish head capsule, but in both, we observed a yellow body with brown spots in each segment. The pupa is elongated and slender, and yellowish brown to mahogany brown in color in both species. The adults are yellowish with black spots in the forewings in both species (Capinera, 2001; Freitas et al., 2006).

Due to high morphological similarities between the two species in all developmental stages, the identification by morphological characters is time-consuming and requires an expert in the morphological analysis of all stages. A quick identification of the two pests' species plays a meaningful role in the pest management in the sugarcane field, e.g., in the choice of the best control method: biological, chemical, or manual collection. Besides the chemical control method (using Triflumuron ${ }^{\circledR}$, Lambdacyhalothrin ${ }^{\circledR}$ and Fipronil ${ }^{\circledR}$ ), the manual collection, and the biological control method using Metarhizium anisopliae (Metsch) and Beauveria bassiana (Bals), the biological control method using Cotesia flavipes (Cameron) is the most applied in Brazil for Diatraea (Mendonça, 1996; Alves, 1998; Alves et al., 2008).

Genetics and Molecular Research 16 (3): gmr16039732 
Cotesia Cameron (Hymenoptera: Braconidae: Microgastrinae) is a large genus with an estimated number of species comprising 1500-2500 and all species described until now are koinobiont endoparasitoids, and it is entirely associated with lepidopteran insects (Gupta et al., 2016). Previous studies show that Cotesia biocontrol is applied on two species of Diatraea, D. grandiosella and D. saccharalis, despite being highly specialized (Alleyne and Wiedenmann, 2001a; Kankare and Shaw, 2004). In Brazil, C. flavipes has been used on biocontrol of the two species included in this study: D. flavipennella and D. saccharalis, but no previous studies were performed to evaluate the response of D. Alavipennella to Cotesia attack (Pinheiro et al., 2010).

The internal transcribed spacer 2 (ITS 2) is a noncoding nucleotide region located inside the ribosomal DNA (rDNA) between the 5,8S and the 28S rRNA sequences. ITS 2 plays an essential role in the maturation of the pre-ribosomal RNA as its secondary structure contained the cleavage sites for the pre-rRNA processing (Marinho et al., 2013). Previous studies showed that ITS 2 is a good molecular marker to phylogenetic inferences among families, subfamilies, and especially as a molecular marker in lower taxonomic groups as genera and species. This nucleotide sequence has been analyzed in many families of Lepidoptera, and in all taxonomic levels, it was observed a variation in length and nucleotide composition of sequences. Therefore, ITS 2 is an efficient barcode for lepidopteran insects and molecular phylogeny of Cotesia species (Kankare and Shaw, 2004; Barr et al., 2009; Wiemers et al., 2009; Wan et al., 2011a).

In this context, this study aimed to available a molecular marker to assist in a rapid and simple identification method of pests' species of Diatraea since the egg stage and to identify possible traces of Cotesia in the resistant host at the adult stage by visualization of ITS 2 amplicons on an electrophoresis agarose gel. Besides, a sequencing of ITS 2 of both Diatraea species was performed to determine the level of difference between them.

\section{MATERIAL AND METHODS}

\section{Egg, larva, and adult achievement and DNA extraction}

A total of 25 eggs, 20 larvae, and 30 adults belonging to the Diatraea flavipennella species from Laboratório de Patologia de Insetos (LPI)/UFRPE, Recife, PE, Brazil, were used. The individuals from LPI were collected at Usina Olho D'água located in Camutanga, Pernambuco. A total of 25 eggs, 25 larvae, and 40 adults belonging to the D. saccharalis species from Rede Interuniversitária para o Desenvolvimento do Setor Sucroalcooleiro (RIDESA), Carpina, PE, Brazil, were used. All individuals from these locations were obtained by breeding. Nine adult specimens of one D. flavipennella natural population were collected at Santa Rita, State of Paraíba, Brazil.

The methodology used for the egg, larva, and adult individuals followed Freitas et al. (2014). Briefly, the individuals were placed in 1.5 -mL plastic tubes with $100 \mu \mathrm{L} \mathrm{5 \%} \mathrm{Chelex}^{\circledR}$ 100 (BioRad, Berkeley, CA, USA). Then, the eggs were macerated with a pestle until reach homogenization, and then they were kept for $1 \mathrm{~h}$ in a water bath at $54^{\circ} \mathrm{C}$. Subsequently, the mixture was transferred to a plastic tube, and it was kept at $94^{\circ} \mathrm{C}$ for $30 \mathrm{~min}$ in the Multigene OptiMax Thermal Cycler TC 9610 (LABNET ${ }^{\mathrm{TM}}$, Edison, NJ, USA). Then, the solution was centrifuged at 13,000 rpm for $6 \mathrm{~min}$, the supernatant was transferred to a $1.5-\mathrm{mL}$ plastic tube, and stocked at $-20^{\circ} \mathrm{C}$. Finally, DNA quantification was carried out in NanoDrop ${ }^{\mathrm{TM}} 1000$ spectrophotometer (Thermo Scientific, Waltham, MA, USA).

Genetics and Molecular Research 16 (3): gmr16039732 


\section{Polymerase chain reaction (PCR)}

For the amplification of the ITS 2, the primers NG02955 (5'-ATG AAC ATC GAC ATT TCG AAC GCA CA-3') and AB052895 (5'-TTC TTT TCC TCC GCT TAG TAA TAT GCT TAA-3'), previously tested in Crambidae species by Wan et al. (2011a), were used in our study. In general, 12.5 $\mu \mathrm{L}$ Mix Go Taq Colorless (Promega ${ }^{\circledR}$ Fitchburg, WI, USA), 7.5 $\mu \mathrm{L}$ nuclease-free water, $1.5 \mu \mathrm{L}$ of each primer, and $2 \mu \mathrm{L}$ template DNA were used. Then, the amplification reactions were carried out in the Multigene OptiMax Thermal Cycler TC 9610 $\left(\mathrm{LABNET}^{\mathrm{TM}}\right.$ ) with the following cycle: initial denaturation at $95^{\circ} \mathrm{C}$ for $3 \mathrm{~min}$; followed by 35 cycles of denaturation at $95^{\circ} \mathrm{C}$ for $30 \mathrm{~s}$, annealing at $60^{\circ} \mathrm{C}$ for $1 \mathrm{~min}$, and extension at $72^{\circ} \mathrm{C}$ for $1 \mathrm{~min}$; and a final extension at $72^{\circ} \mathrm{C}$ for $7 \mathrm{~min}$. The amplification products were analyzed by $3 \%$ agarose electrophoresis gel, which ran for $60 \mathrm{~min}$ at $120 \mathrm{~V}$. Then, the amplicons were stained with Bluegreen (LGC Biotecnologia, São Paulo, SP, Brazil), and visualized in UV transilluminator.

\section{Amplicon purification and sequencing}

The amplicon purification was performed using the Wizard $^{\circledR}$ SV Gel and PCR Clean-Up System kit (Promega ${ }^{\circledR}$ ), following the manufacturer's instructions. Subsequently, purified amplicon sequencing was carried out in the ABI 3500 automated sequencer (Applied Biosystems, Cleveland, OH, USA). Then, the sequences were evaluated using the programs Pregap4 v 1.5 and Gap4 incorporated into the Staden Package (Staden, 1996), using Phred value equal to 30 as a quality cutoff. Similarity searches in GenBank were performed using BLASTn (Altschul et al., 1990). The sequences were aligned in MEGA 5.05 by the Muscle method (Edgar, 2004; Tamura et al., 2011). The microsatellite mining was performed in Microsatellite Repeats Finder available online (Bikandi et al., 2004). The sequences were deposited in GenBank database (http://www.ncbi.nlm.nih.gov/) under the following accession numbers: KT288209, KT288210, KT288211, KT288212, KT288213, KT288214, KT288215, KT288216, KT288217, KT288218, KT288219, KT288220, KT288221， KT288222, KT288223, KT288224, and KT288225.

\section{RESULTS}

The ITS 2 amplicons visualized on the electrophoresis gel from the eggs, larvae, and adults of $D$. flavipennella showed about $580 \mathrm{bp}$ in length, while $D$. saccharalis amplicons showed about $610 \mathrm{bp}$ in length (Figure 1). The adult specimens of D. Alavipennella ITS 2 sequences from the State of Paraíba showed about $580 \mathrm{bp}$ in length, perhaps three of them showed an additional band with approximately $400 \mathrm{bp}$ in length (Figure 2). These two additional amplicons were also purified and sequenced.

Five (three from larvae and two from adults) and four (all samples from adult individuals) ITS 2 sequences were obtained from D. flavipennella by breeding and natural populations from the State of Paraíba, respectively. Seven (six from larvae and one from the adult) ITS 2 sequences were obtained from $D$. saccharalis. The sequences ranged from 575

to $613 \mathrm{bp}$. We aligned the ITS 2 sequences with the GenBank using BLASTn (Altschul et al., 1990), and observed $101 \mathrm{bp}$ from 5,8S rDNA and $60 \mathrm{bp}$ from 28S rDNA included in these amplicons. After the identification of the rDNA sequences, they were removed from the

Genetics and Molecular Research 16 (3): gmr16039732 
analysis. The additional DNA band observed on the electrophoresis gel of the D. flavipennella population from Paraíba showed $367 \mathrm{bp}$ and matched with ITS 2 sequences from Cotesia available in GenBank.

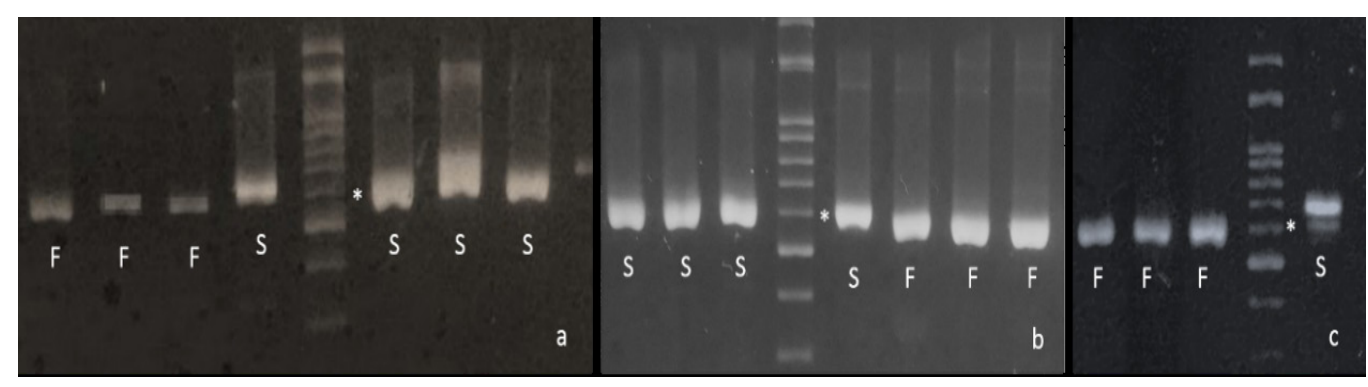

Figure 1. Electrophoresis gel showing length differences among ITS 2 amplicons of Diatraea flavipennella and $D$. saccharalis from three developmental stages: egg (a), larvae (b), and adult (c). Lane F: D. flavipennella, and lane $S:$ D. saccharalis. Asterisk indicates a 600-bp band.

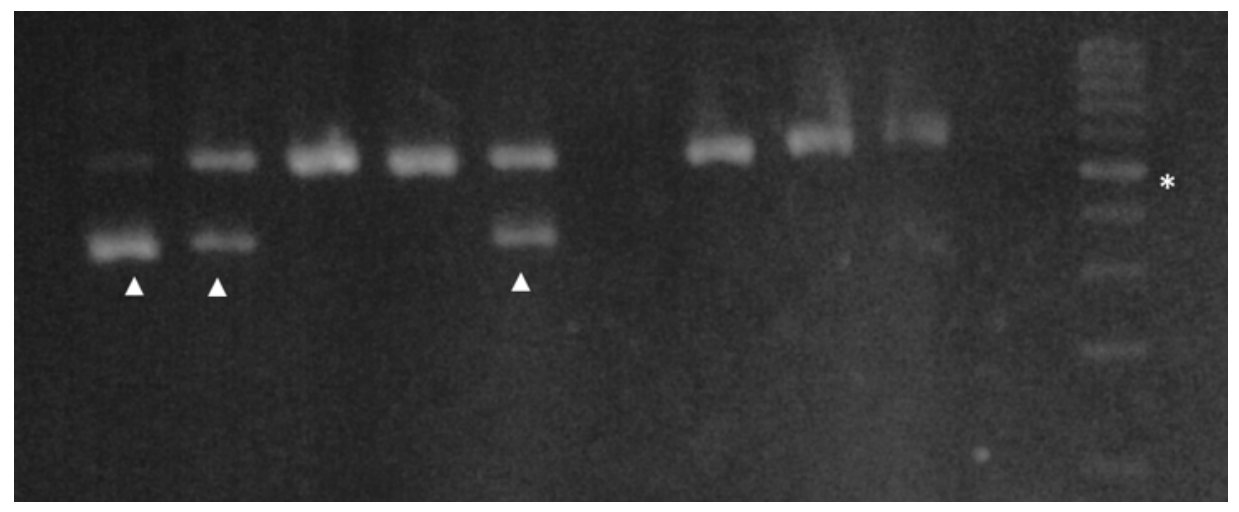

Figure 2. Electrophoresis gel showing an additional band of about $400 \mathrm{bp}$ found in the PCR using ITS 2 primers in Diatraea flavipennella individuals. Arrowheads indicate the additional bands and asterisk indicates a 500-bp band.

The D. flavipennella and D. saccharalis sequences presented indels, which result in ITS 2 length variation between the two species. The ITS 2 loci present 410 bp in D. flavipennella and $448 \mathrm{bp}$ in D. saccharalis. The ITS 2 average nucleotide composition was similar between these two species: $30.3 \%$ thymine; $22.3 \%$ cytosine; $20 \%$ adenine, and $27.4 \%$ guanine. The average GC content was $48 \%$ in D. flavipennella and $51 \%$ in D. saccharalis. It was not observed any variability among individuals of the $D$. flavipennella species. Perhaps, among the D. saccharalis individuals, a 3-bp indel was observed. In D. flavipennella and D. saccharalis ITS 2 sequences, the presence of microsatellites was observed, and there were slight differences in the microsatellite distribution (Table 1).

AmongtheITS2DNAsequences fromthetwospecies D. Alavipennella and D. saccharalis, we found four conservative DNA sites. After the 5.8S rDNA, we observed a 31-bp DNA sequence 5'-TTYTTCGAAACGGTGTTGACCGTTCTCCTCC-3' with a thymine in D. Alavipennella and a cytosine in $D$. saccharalis at the third position of this sequence. An indel (guanine) at the fourth position in $D$. saccharalis was also observed. The second sequence was identical between 
these two species with $21 \mathrm{bp}, 5$ '-GAGTCGGTTTAAATATATTAC-3'. The third sequence has $42 \mathrm{bp}, 5^{\prime}$-ACGCGTGTCGTTCTCGATATAGAAAGCGACTCTTTGTGGATG-3', also identical between these two species. The fourth conservative site is a DNA sequence with 127 bp in D. flavipennella and 131/133 in D. saccharalis; between these sequences, some indels and nucleotide changes were observed (see Figure 3).

Table 1. Microsatellite repeats found in Diatraea flavipennella and D. saccharalis.

\begin{tabular}{l|c|c|c|c}
\hline SSR & \multicolumn{2}{|c|}{ Position } & \multicolumn{2}{c}{ Repetition } \\
\hline & D. flaviepnnella & D. saccharalis & D. flaviepennella & Daccharalis \\
\hline AT & $59,200,238$, and 257 & 61 & 3 and 4 & 3 \\
\hline AG & 290 & 271 and 290 & 3 & 6 \\
\hline GT & 70 & 243 & 3 & 3 \\
\hline AC & - & 124 & - & 3 \\
\hline CGT & 332 and 352 & 368 & 3 and 7 & 4 \\
\hline GCG & 322 & 355 & - & 3 \\
\hline GAC & - & 78 & - & 6 \\
\hline TCG & - & 392 & - & \\
\hline
\end{tabular}

SSR: simple sequence repeats.

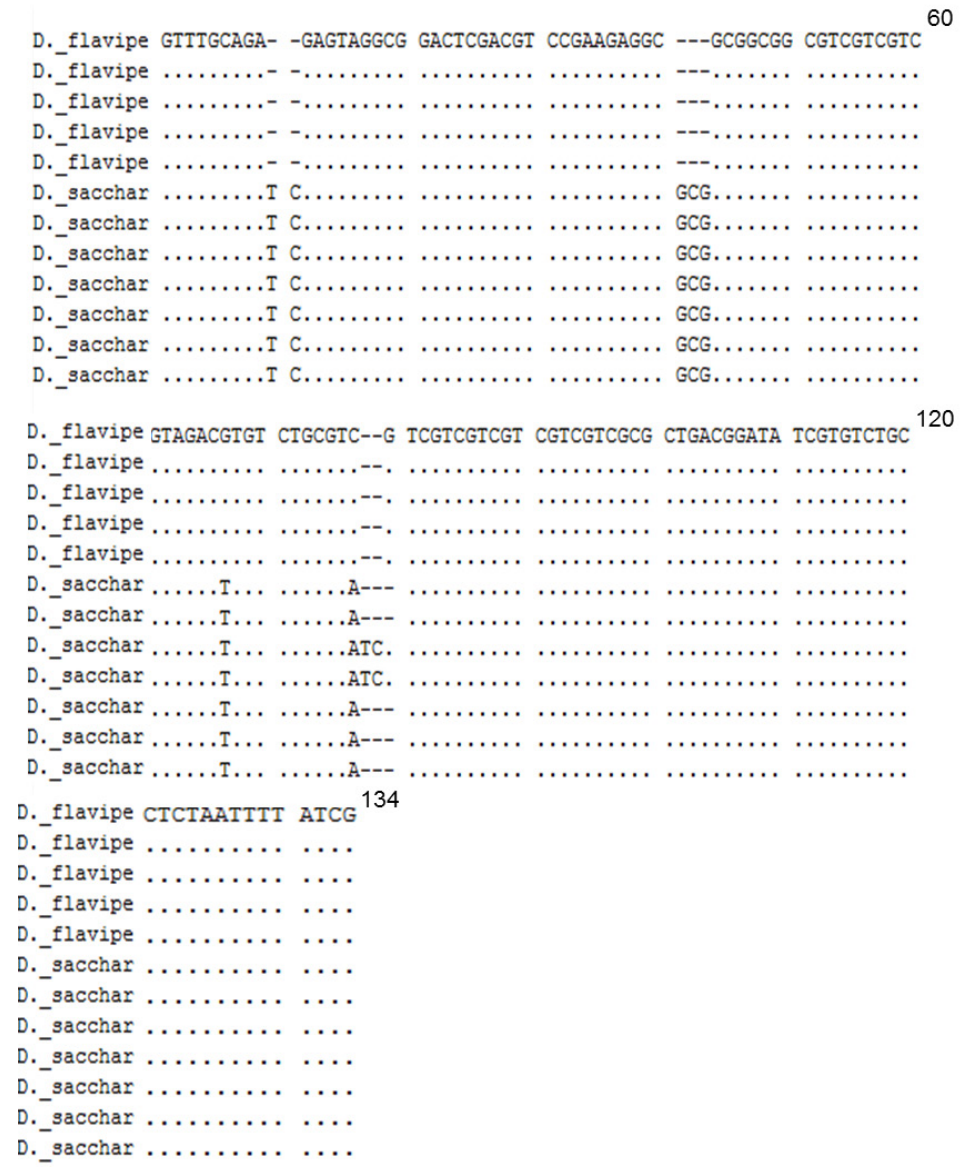

Figure 3. Alignment of ITS 2 segment 4 from Diatraea flavipennella and D. saccharalis.

Genetics and Molecular Research 16 (3): gmr16039732 


\section{DISCUSSION}

The ITS 2, located between the 5.8S and 28S rDNA, has many valuable characteristics that can make it a good candidate for DNA barcode and, according Yao et al. (2010), one of them possesses sufficient variation among the sequences to discriminate species and needs to be conserved so that there is less variability within species than between species. The amplified ITS 2 fragments visualized on electrophoresis agarose gel showed distinct sizes in each Diatraea species included in this study. This rDNA region has been used to identify many lepidopteran species and other insect orders without the need to be sequenced, but only comparing the amplicon sizes on agarose gel (Barr et al., 2009; Wan et al., 2011a; Sayed et al., 2013; Zomuanpuii et al., 2013). In the sugarcane field, in many cases, we only find pieces of the Diatraea larvae due to cuts in the sugarcane or eggs, but these situations are difficult to identify. Therefore, a molecular marker that allows the researcher or the professional who works with Diatraea control to perform a quick identification with a lower cost is very competitive.

ITS 2 sizes from D. flavipennella and D. saccharalis showed 410 and $448 \mathrm{bp}$, respectively, confirming the observed variation on an electrophoresis gel. The observed length variation between species could be due to insertions induced by many factors including the relative number and sizes of microsatellite repetitions, unequal crossing over, gene conversion, or genetic drift (Levinson and Gutman, 1987). More changes lead to bigger variations in the ITS 2 sequence size that will be the effect on the secondary structure conservation (Kuracha et al., 2006).

Among the species that belong to the Family Crambidae analyzed until now, we could observe that the average size of the ITS 2 region in that group is $445 \mathrm{bp}$, represented by the species, Chilo hyrax (488 bp), C. supressalis (484 bp), Cnaphalocrocis medinalis (447 bp), and Maruca vitrata (451 bp), while ITS 2 in O. nubilalis is $390 \mathrm{bp}$ (Margam et al., 2011; Wan et al., 2011a). The ITS 2 region size is specific to each species in the family Crambidae, and this also happens in other families as Tortricidae, Noctuidae, Geometridae, and Lycaenidae (Barr et al., 2009; Wiemers et al., 2009; Wan et al., 2011a; Kvie et al., 2012).

In the ITS 2 from both species, eight different microsatellite sequences were found. Among them, five (AT, GT, AG, GCG, and CGT) were present in both Diatraea species, but in some cases the repetition numbers were different. The dinucleotide $\mathrm{AC}$ and the trinucleotides GAC and TCG were only found in D. saccharalis; therefore, the insertion of these sequences in $D$. saccharalis or deletion of them in D. flavipennella may be contributed to differences in total sequence sizes. There was no intraspecific variation according to sequence length among D. flavipennella individuals from both populations, and in D. saccharalis two individuals showed an increase of three nucleotides. The sequence size homogenization among individuals, in the case of D. saccharalis and D. flavipennella by breeding, could be due to endogamy that is present in breeding. There was also no report about significant ITS 2 size differences in some lepidopteran species: Chilo sp, Cnaphalocrocis medinalis, Ostrinia sp, Spodoptera spp, Polyommatus spp, and species from the families Geometridae, Lasiocampidae, Pieridae, Tortricidae, and Zygaenidae (Niehuis et al., 2006; Barr et al., 2009; Wiemers et al., 2009; Dincă et al., 2011; Margam et al., 2011; Wan et al., 2011a; Kvie et al., 2012). In other groups as Diptera, ten species belonging to genus Anopheles, from different geographic regions, did not also show intraspecific differences in nucleotide composition and sequence length. The authors attributed this phenomenon to a lack of environmental barriers and the concerted evolution that maintains the homogeneity of all rDNA copies that can lead to intraspecific homogeneity (Zomuanpuii et al., 2013). We found the same situation to both populations of

Genetics and Molecular Research 16 (3): gmr16039732 
D. flavipennella, where there is no ecological barrier between populations from Pernambuco and Paraíba.

The GC content had low variation between the two species in this study. When we compare the value found in the Diatraea species with other species from Crambidae we can observe a similar GC content among them. Cnaphalocrocis medinalis and M. vitrata showed, respectively, 47.8 and $45.1 \%$ GC. However, Chilo suppressalis and C. hyrax, which are closely related to Diatraea, showed 57.2 and $55.2 \%$ GC; the higher values observed until now (Margam et al., 2011; Wan et al., 2011a). When we observe the GC content from other families, we can see a significant increase compared to Crambidae, as in Tortricidae (61\%) and Noctuidae $(58.6 \%)$, but this increase happens in both basal and advanced groups (Barr et al., 2009; Wan et al., 2011b). The GC content to Lepidoptera is considered comparatively high, and this can affect the energy of the secondary structure (Banerjee et al., 2007).

D. flavipennella and D. sacharalis ITS 2 sequence alignment showed four conserved sites that correspond to 53.6 and $49.1 \%$ of ITS 2 sequences from D. flavipennella and D. saccharalis, respectively. These conserved sites are intercalated by variable regions. Even though they are highly conserved, these regions show differences that characterize each Diatraea species, as indels and base substitutions. Mai and Coleman (1997) presented the reason for this apparent alternation between conserved and variable sites. According to the authors, those conserved regions contribute to secondary structure helices, pairing where the RNA transcription begins, and this secondary structure leads the process.

Parasitic wasps that belong to Cotesia flavipes species are used as biological control of stem borers that attack some crops like sorghum, rice, maize, and sugarcane. $D$. saccharalis, D. flavipennella, D. grandiosella, and $O$. nubilalis are among the crambids affected by that parasitoid (Hall et al., 1991; Alleyne and Wiedenmann 2001a,b; Bortoli et al., 2005; Araújo et al., 2010). When the host is parasitized by Cotesia the host's immune system applies some defensive strategies to combat those parasitoids by humoral (production of antimicrobial peptides, reactive intermediates of oxygen and nitrogen, coagulation, or melanization) and cellular defenses (defenses mediated by hemocytes through phagocytosis, nodulation, and encapsulation) (Strand and Pech, 1995; Gillespie et al., 1997; Lowenberger, 2001; Vass and Nappi, 2001; Schmidt et al., 2001). However, parasitic wasps have some strategies to suppress the host's immune system to maintain the parasite integrity inside the host. The strategies involve maternal factors as ovarian proteins, and polydnavirus and embryonic factors as teratocytes.

According to our results, where we could identify the parasitoid in adults $D$. flavipennella using ITS 2 marker, we can speculate that D. flavipennella have unknown mechanisms that dribble the immunosuppression caused by Cotesia. Rodríguez-Pérez et al. (2005), in a study with C. flavipes and Manduca sexta, observed that parasitism was unable to induce host immunosuppression in the non-habitual host. In habitual hosts, as D. saccharalis, parasitism induces host immunosuppression that is required to prevent encapsulation of Cotesia parasitoid (Alleyne and Wiedenmann, 2001b; White and Wilson, 2012). The status of the distribution of $D$. flavipennella and $D$. saccharalis in the northeast sugarcane fields supports the idea of host refractoriness by $D$. flavipennella. It was observed an inversion of species dominance where the prevalence of D. flavipennella was $97.67 \%$ over $2.33 \%$ of $D$. saccharalis, and the authors attributed that inversion to inefficient methods of biological control as $C$. flavipes, for example, that may favor D. flavipennella instead of $D$. saccharalis (Freitas et al., 2006).

Genetics and Molecular Research 16 (3): gmr16039732 
In summary, we can conclude that ITS 2 molecular marker is efficient to identify $D$. flavipennella and $D$. saccharalis in any developmental stage with accuracy by electrophoresis gel or sequencing. ITS 2 was also used to identify traits of Cotesia spp parasitoid in adults $D$. flavipennella. With this information, we can speculate a reason that justifies the inversion of species dominance in the sugarcane field that is the host refractoriness of D. flavipennella, but further studies are required to prove that.

\section{ACKNOWLEDGMENTS}

We are grateful to Dr. Heidi Lacerda for her technical support in DNA sequencing. The authors also acknowledge Rede Interuniversitária para o Desenvolvimento do Setor Sucroalcooleiro (RIDESA) and the Platform for Genomics and Gene Expression of Universidade Federal de Pernambuco for the logistic and technical assistance. We are also grateful to Dr. Herbert Siqueira and Dr. Jacinto Marques for donating the Diatraea specimens used in this study. This study was supported by the Brazilian funding agencies Fundação de Amparo à Ciência e Tecnologia do Estado de Pernambuco (FACEPE), Conselho Nacional de Desenvolvimento Científico e Tecnológico (CNPq), and the Bioethanol Research Network of the State of Pernambuco (CNPq-FACEPE/PRONEM program, process \#APQ-1452-2.01/10).

\section{REFERENCES}

Alleyne M and Wiedenmann RN (2001a). Suitability of lepidopteran stemborers for parasitization by novel-association endoparasitoids. BioControl 46: 1-23. https://doi.org/10.1023/A:1009918123138

Alleyne M and Wiedenmann R (2001b). Encapsulation and total hemocyte numbers in three lepidopteran stemborers parasitized by Cotesia flavipes-complex endoparasitoids. Entomol. Exp. Appl. 100: 279-293. https://doi.org/10.1046/ j.1570-7458.2001.00875.x

Altschul SF, Gish W, Miller W, Myers EW, et al. (1990). Basic local alignment search tool. J. Mol. Biol. 215: 403-410. https://doi.org/10.1016/S0022-2836(05)80360-2

Alves SB (1998). Fungos Entomopatogênicos. In: Controle microbiano de insetos (Alves SB, ed.). FEALQ, Piracicaba, 289-381.

Alves SB, Lopes RB, Vieira SA and Tamai MA (2008). Fungos entomopatogênicos usados no controle de pragas na América Latina. In: Controle microbiano de pragas na América Latina: avanços e desafios (Alves SB and Lopes RB, eds.). FEALQ, Piracicaba, 69-110.

Araújo LF, Bento LE, Romano JGJ, Horvathy AN, et al. (2010). Incidência de Spodoptera frugiperda, Diatraea saccharalis e Doru luteipes no Milho Convencional e Transgênico Bt Cultivados na Safrinha. Annals of the Congresso Nacional do Milho e do Sorgo, Goiânia, Brazil, 460-467.

Banerjee AK, Arora N and Murty US (2007). Stability of ITS2 secondary structure in Anopheles: what lies beneath? Int. J. Integr. Biol. 1: 232-238.

Barr NB, Ledezma LA, Vasquez JD, Epstein M, et al. (2009). Molecular identification of the light brown apple moth (Lepidoptera: Tortricidae) in California using a polymerase chain reaction assay of the internal transcribed spacer 2 locus. J. Econ. Entomol. 102: 2333-2342. https://doi.org/10.1603/029.102.0640

Bikandi J, San Millán R, Rementeria A and Garaizar J (2004). In silico analysis of complete bacterial genomes: PCR, AFLP-PCR and endonuclease restriction. Bioinformatics 20: 798-799. https://doi.org/10.1093/bioinformatics/btg491

Bortoli SA, Dória HOS, Albergaria NMMS and Botti MV (2005). Aspectos biológicos e dano de Diatraea saccharalis (Fabr., 1794) (Lepidoptera: Pyralidae) em sorgo cultivado sob diferentes doses de nitrogênio e potássio. Cienc. Agrotec. 29: 267-273. https://doi.org/10.1590/S1413-70542005000200001

Capinera JL (2001). Sugarcane Borer, Diatraea saccharalis (Fabricius) (Insecta: Lepidoptera: Pyralidae). Available at [http://edis.ifas.ufl.edu/pdffiles/IN/IN37400.pdf]. Accessed March 5, 2013.

Dincă V, Lukhtanov VA, Talavera G and Vila R (2011). Unexpected layers of cryptic diversity in wood white Leptidea butterflies. Nat. Commun. 2: 324. https://doi.org/10.1038/ncomms1329

Edgar RC (2004). MUSCLE: multiple sequence alignment with high accuracy and high throughput. Nucleic Acids Res. 32:

Genetics and Molecular Research 16 (3): gmr16039732 
1792-1797. https://doi.org/10.1093/nar/gkh340

Freitas MRT, Fonseca APP, Silva ED, Mendonça AL, et al. (2006). The predominance of Diatraea flavipennella (Lepidoptera: Crambidae) in sugar cane fields in the State of Alagoas, Brazil. Fla. Entomol. 89: 539-540. https://doi. org/10.1653/0015-4040(2006)89[539:TPODFL]2.0.CO;2

Freitas MTS, Gomes-Júnior PP, Batista MVA, Leal-Balbino TC, et al. (2014). Novel DNA extraction assay for molecular identification of Aedes spp eggs. Genet. Mol. Res. 13: 8776-8782.

Gillespie JP, Kanost MR and Trenczek T (1997). Biological mediators of insect immunity. Annu. Rev. Entomol. 42: 611643. https://doi.org/10.1146/annurev.ento.42.1.611

Gupta A, Shaw M, Cardinal S and Fernandez-Triana J (2016). A review of unusual species of Cotesia (Hymenoptera, Braconidae, Microgastrinae) with the first tergite narrowing at midlength. ZooKeys 580: 29-44. https://doi. org $/ 10.3897 /$ zookeys.580.8090

Hall DG, Nuessly GS and Gilbert RA (1991). Sugar cane borer in Florida. University of Florida, IFAS Extension. ENY666: 1-3. Available at [http://ufdcimages.uflib.ufl.edu/IR/00/00/30/41/00001/SC01100.pdf]. Accessed March 1, 2013.

Kankare M and Shaw MR (2004). Molecular phylogeny of Cotesia Cameron, 1891 (Insecta: Hymenoptera: Braconidae: Microgastrinae) parasitoids associated with Melitaeini butterflies (Insecta: Lepidoptera: Nymphalidae: Melitaeini). Mol. Phylogenet. Evol. 32: 207-220. https://doi.org/10.1016/j.ympev.2003.11.013

Kuracha M, Rayavarapu B, Kumar S and Rao P (2006). Comparison Of Secondary Structure Of The Ribosomal Internal Transcribed Spacer 2 (ITS2) Of Eight Lepidopteran Species From Diverse Geographical Locations. J. Entomol. 3: 222-230. https://doi.org/10.3923/je.2006.222.230

Kvie KS, Hogner S, Aarvik L, Lifjeld JT, et al. (2012). Deep sympatric mtDNA divergence in the autumnal moth (Epirrita autumnata). Ecol. Evol. 3: 126-144. https://doi.org/10.1002/ece3.434

Levinson G and Gutman GA (1987). Slipped-strand mispairing: a major mechanism for DNA sequence evolution. Mol. Biol. Evol. 4: 203-221.

Lowenberger C (2001). Innate immune response of Aedes aegypti. Insect Biochem. Mol. Biol. 31: 219-229. https://doi. org/10.1016/S0965-1748(00)00141-7

Mai JC and Coleman AW (1997). The internal transcribed spacer 2 exhibits a common secondary structure in green algae and flowering plants. J. Mol. Evol. 44: 258-271. https://doi.org/10.1007/PL00006143

Margam VM, Coates BS, Ba MN, Sun W, et al. (2011). Geographic distribution of phylogenetically-distinct legume pod borer, Maruca vitrata (Lepidoptera: Pyraloidea: Crambidae). Mol. Biol. Rep. 38: 893-903. https://doi.org/10.1007/ s11033-010-0182-3

Marinho MAT, Azeredo-Espin AML and Zanchin NIT (2013). Structural characterization of the internal transcribed spacer 2 (ITS2) of the ribosomal DNA (rDNA) cluster in Calyptratae (Diptera: Schizophora) and its implications for molecular phylogenetic analyses. J. Mol. Evol. 76: 158-171. https://doi.org/10.1007/s00239-013-9548-1

Mendonça AF (1996). Pragas da cana-de-açúcar. Insetos \& Cia, Maceió.

Niehuis O, Yen SH, Naumann CM and Misof B (2006). Higher phylogeny of zygaenid moths (Insecta: Lepidoptera) inferred from nuclear and mitochondrial sequence data and the evolution of larval cuticular cavities for chemical defence. Mol. Phylogenet. Evol. 39: 812-829.

Pinheiro DO, Zucchi TD, Zucchi OLAD, Nascimento Filho VF, et al. (2010). Inorganic elements in the fat bodies of Diatraea saccharalis (Lepidoptera: Crambidae) larvae parasitized by Cotesia flavipes (Hymenoptera: Braconidae). Comp. Biochem. Physiol. B Biochem. Mol. Biol. 156: 273-278. https://doi.org/10.1016/j.cbpb.2010.04.004

Rodríguez-Pérez MA, Dumpit RF, Lenz JM, Powell EN, et al. (2005). Host refractoriness of the tobacco hornworm, Manduca sexta, to the braconid endoparasitoid Cotesia flavipes. Arch. Insect Biochem. Physiol. 60: 159-171. https:// doi.org/10.1002/arch.20102

Sayed SM, Montaser MM, Elsayed G and Amer SAM (2013). Preliminary molecular identification of a predatory bug, Orius albidipennis, collected from ornamental plants. J. Insect Sci. 13: 11. https://doi.org/10.1673/031.013.1101

Schmidt O, Theopold U and Strand MR (2001). Innate immunity and evasion by hymenopteran parasitoids. BioEssays 23: 344-351. https://doi.org/10.1002/bies.1049

Staden R (1996). The Staden sequence analysis package. Mol. Biotechnol. 5: 233-241. https://doi.org/10.1007/BF02900361

Strand MR and Pech LL (1995). Immunological basis for compatibility in parasitoid-host relationships. Annu. Rev. Entomol. 40: 31-56. https://doi.org/10.1146/annurev.en.40.010195.000335

Tamura K, Peterson D, Peterson N, Stecher G, et al. (2011). MEGA5: molecular evolutionary genetics analysis using maximum likelihood, evolutionary distance, and maximum parsimony methods. Mol. Biol. Evol. 28: 2731-2739. https://doi.org/10.1093/molbev/msr121

Vass E and Nappi AJ (2001). Fruitfly immunity. BioEssays 51: 529-535.

Wan X, Li J, Kim MJ, Kang TH, et al. (2011a). Population genetic structure of the migratory rice leaf roller, Cnaphalocrocis

Genetics and Molecular Research 16 (3): gmr16039732 
medinalis (Lepidoptera: Pyralidae), inferred from the mitochondrial A+T-rich region and nuclear ITS2 sequences. Genet. Mol. Res. 10: 273-294. https://doi.org/10.4238/vol10-1gmr1005

Wan X, Li J, Kim MJ, Park HC, et al. (2011b). DNA sequence variation of the tobacco cutworm, Spodoptera litura (Lepidoptera: Noctuidae), determined by mitochondrial A+T-rich region and nuclear ITS2 sequences. Biochem. Genet. 49: 760-787. https://doi.org/10.1007/s10528-011-9449-1

White WH and Wilson LT (2012). Feasibility of using an alternative larval host and host plants to establish Cotesia flavipes (Hymenoptera: Braconidae) in the temperate Louisiana sugarcane ecosystem. Environ. Entomol. 41: 275-281. https:// doi.org/10.1603/EN11095

Wiemers M, Keller A and Wolf M (2009). ITS2 secondary structure improves phylogeny estimation in a radiation of blue butterflies of the subgenus Agrodiaetus (Lepidoptera: Lycaenidae: Polyommatus ). BMC Evol. Biol. 9: 300. https:// doi.org/10.1186/1471-2148-9-300

Yao H, Song J, Liu C, Luo K, et al. (2010). Use of ITS2 region as the universal DNA barcode for plants and animals. PLoS One 5: e13102. https://doi.org/10.1371/journal.pone.0013102

Zomuanpuii R, Ringngheti L, Brindha S, Gurusubramanian G, et al. (2013). ITS2 characterization and Anopheles species identification of the subgenus Cellia. Acta Trop. 125: 309-319. https://doi.org/10.1016/j.actatropica.2012.12.001

Genetics and Molecular Research 16 (3): gmr16039732 